\title{
Analysis and Research on the phenomenon of college students cheating in the exam in Education
}

\author{
Rong Yu \\ College of Media Sciences, Changchun Normal University, Changchun, Jilin, 130032, China \\ email:rongyu1126@163.com
}

Keywords: Education of College Students; Cheating in the exam; Analysis and research; Undergraduate education

\begin{abstract}
The current university students in the education process before the Exam Cram, collective to cheat in the examination, the examination is always playing the phenomenon studied. Through interviews and questionnaires and actual investigation found that learning for the students very negative attitude. In the absence of life lost confidence and interest in learning. In order to cope with the exam cheating often use. In view of this phenomenon in a series of educational methods is proposed. The ideological and political education as a means to fundamentally solve the current students impetuous mentality. Through the practice of these methods have found on current college students in-depth education function, can be applied.
\end{abstract}

\section{Introduction}

The college students' cheating problem have kept a long-standing, they often through a series of cheating means and their study asymmetry scores. Cheating problems in school education is one of the most devastating problem[1]. Cheating phenomenon directly led to the cheaters" unearned" has been often requires long-term efforts to learn to get results, if successful the cheaters cheat will be a great encouragement, will promote the study in the future are also counted by cheating ways to gain income, but not study hard. Other efforts to learn without cheating found other cheating by means of cheating to obtain higher scores than their own, in their mental state will cause great blow, they will think it is an unfair phenomenon, on their learning enthusiasm will cause greater impact [2-3]. Previous cheating in school can easily be found and treated, thus cheating will give cheaters brings bigger risk. But with the current high-tech cheating, cheating means more concealment, and due to various reasons the school or the invigilator cheating" tend to open one eye, one eye closed". The existence of this kind of problem directly as cheating in the university campus in flooding provides conditions. The school education is very adverse, how in the system and action to solve the flooding problem of college Students' cheating in exams, a direct impact on a college education quality and external education reputation.

\section{The Examination Cheating Case}

According to reports in the university English four, six levels of tests just spend hundreds of yuan equipment cost and information cost can be almost 70\% accuracy of the examination answer. June 10, 2010 to 15 consecutive Harbin CCTV University English four, six steps of examination cheating flooding problem. This opened the college students cheating in examinations in a corner of the flooding problem. And this for candidates and to provide means of cheating organizations have formed a huge industrial chain and the industrial chain through the operation of the market has been quite mature. Provide cheating equipment" company" almost certainly guarantee, promise" exam but may refund". The integrity of the slogan is that the college students cheating in examinations in the industrial chain, each side has the cheating the integrity of the operating mode to obtain customer. Cheating is originally a very inglorious" mouse shaggier enemies" problem, but in the current circumstances seem to be coping examination cheating has become a necessary weapon, has broken through the bottom line of morality. This flood of popular cheating problem can be said is 
that we college education. In the integrity of the social cheating itself is a kind of non integrity embodied, and cheating industry adopted a "good faith" means to the integrity of the challenge. Cheating either among the students in educational institutions intermediate seems to be allowed and required. This status quo of education 's attack is very serious, cheating at interest, many students buy high-tech cheating ( equipped with liquid crystal display rubber, signal receiving eyes, yellow bean earphone ) to achieve its purpose, and" popularity" phenomenon and further promote cheating more rampant, the school education quality caused by heavy blow. And this in turn caused further against cheating. Such a vicious spiral of university education equity is a great threat.

College Students' cheating in examination is the severity of almost beyond our imagination. In the discussion of this problem we use survey and analysis method. Based on some college students' random investigation and individual random interviews, we found that during previous examinations have cheating students was $94 \%$, in a recent years cheating students accounted for $75 \%$. In general the mid-term or final examination of the use of high-tech means numbers are very small, and in the four six stage have an exam and the graduate student entrance examination of such national high security examination of the use of high-tech means of cheating accounted for $80 \%$ of the number of cheaters. The students benefit from cheating accounts for $70 \%$ of total number, because the cheating problem subjected to disciplinary treatment of cheating accounted for $4 \%$ of the number of cheaters. This low cheating probability and high income is also the current college students' cheating in Exams Cheating the direct cause of flooding.

\section{The Reason of the Cheating in College}

College students in the examination especially national important cheat in the examination. There are a lot of reasons for the status of. From the social integrity and impulsive effects, but also from the management of the school for cheating, corruption and lax discipline as well as to promote students' Utilitarian impetuous, and from the social cheating industry supervision is not strict, the rule of law is not perfect, execute the law lax problem.

The current our country the rich and poor differentiation is serious, seems to have formed a privileged class. They hold most of the resources and wealth of society. They get this treatment method is not honest work, dedication, and on the contrary, they often through a variety of bad faith, to get legal chance means among the class. The society of integrity in the entire society has been widely applied. From show level to look dishonest means gain is much higher than its risk. This trend will spread to every corner of the society, the university is natural also cannot escape. Can think this kind of social effects of College Students' cheating is rampant deep-seated and fundamental reason. The school often in cheating in policy formulation is very detailed and very strict, but in practice are often not just as one wishes. Schools in the treatment of students cheating has its own considerations, to a certain extent, the school is also cheating beneficiaries, such as in the national examinations in their students by means of cheating to obtain much higher than its level of achievement, which greatly improves the visibility of the school, the school employment, enrollment is good help. Therefore in the examination of major colleges and universities do not really cheating students were severely punished. The school is the cause of students' cheating ' direct cause. On the side of the students, due to a variety of atmosphere's influence, cheating is considered a become inured to the unusual phenomenon, even the students held a symposium to discuss cheating cheating methods. The reasons caused today college students' cheating in the exam form industrialization.

\section{How to Prove the Examination Cheating in College}

The current college student cheating overrun of especially the root, to solve these problems and contradictions will be able to reduce or even eliminate the student cheating. As cheating problem cause is many-sided, therefore to solve the issues also need much effort. In the propaganda of public opinion to promote integrity, to the society of sincere letter phenomenon effectively combat, especially to solve the problem of social stratification, true implementation politics, social credit 
situation, at the same time, the industry chain were effective against cheating. This work is a long-term process, need courage and boldness in. The school requires attention to their long-term interests is not only the immediate interests, resolutely crack down on cheating, using more advanced methods and system to eliminate the examination cheating. Let the cheaters had no place to hide, so that we can create a good learning atmosphere, the student energy transfer to study hard. In the school the teacher to realize students' education is not only the completion of classroom tasks, more important is to solve the students' study and thought in the problem of existence, true implementation" preaching, imparting knowledge, doubts" the responsibility of teachers. Counselors and teachers closely to improve the ideological and political education of students quality. Let the learning atmosphere in the University flourished.

\section{Conclusion}

This article on College Students' cheating on the investigation and analysis of College Students' cheating, flood situation reason undertook thorough analysis, and put forward a series of effective proposals and measures, can be applied in Colleges and universities. After the pilot study found that using these prevent students cheating means can greatly reduce the students' cheating motive, improve teaching style.

\section{References}

[1] Guo Yonghui. Based on situational crime prevention theory of College Students' cheating behavior control [J ]. Science Forum.2009,33:57,72.

[2] Rong Yu. The Policy Analyze for Academician Attendance Variety in Classroom Teaching. International Conference on Eduction and Sports Education. 2010 INTERNATIONAL CONFERENCE ON EDUCATION AND SPORTS EDUCATION, VOL II: 94-97,2010.

[3] Rong yu. Implementing ideological and political education in university classroom teaching Proceedings - 2010 International Conference on Artificial Intelligence and Education, ICAIE 2010, 321-323, 2010, Proceedings - 2010 International Conference on Artificial Intelligence and Education, ICAIE 2010. 